\title{
Assessing the Need for Developing and Managing Recreational Facilities In Nigeria
}

\author{
${ }^{1}$ Officha, M.C., ${ }^{2}$ Onwuemesi, F.E. ${ }^{1}$ Enete, I.C.; ${ }^{1}$ Nzeamalu, I.C. \\ ${ }^{I}$ Department of Architecture, Nnamdi Azikiwe University, Awka, Anambra state, Nigeria. \\ ${ }^{2}$ Department of Environmental Management, Nnamdi Azikiwe University, Awka, Anambra State, Nigeria.
}

\begin{abstract}
The negligence of adequate planning and development of recreational facilities in Nigeria is a huge setback to cities achieving maximum utilization in their social, economic, physical and environmental sectors. This is coupled with many other managerial problems in maintaining the few available ones; and as such it has led to gradual decay of the nation's recreational areas and, hence reduced their benefit to the built environment. These benefits include general beauty, healthy lifestyles, increased leisure activities, communal interaction and preservation of natural system and maximizing abandoned land spaces. Assessing this need is valuable as the continuous growth of urban areas without considering the planning, development and management of recreational areas has led to the unpleasant environmental consequences. Using secondary source of data gathering, the paper reviews literatures on the general need for developing recreational facilities in Nigeria and critically examines the planning and development designs, the important facilities and management procedures for recreational areas. It asserts that there is a need for an improvement in landscape planning through effective physical planning, aesthetic management, development control/schemes and the enforcement of adequate management techniques.
\end{abstract}

Keyword: Recreational facility, development, design, Management, Open spaces.

\section{Introduction}

Increased population in Nigerian cities has led to the demand of more land spaces for other land uses like residential, commercial, industrial, agricultural and industrial activities at the expense of recreational and open spaces (Ogundele and Jegede, 2011). This has resulted in multiple developments of squatter settlement, ghettos and illegal structures that describe our urban settings and once beautiful cities (Fasakin, 2009, Alabi, 2010 and Aluko, 2011). It is to be noted that this fast growing developments are not accompanied by necessary planning, development designs and physical planning provision; hence, unguided and uncontrolled developments are prevalent (Olujimi, 2009; Alabi, 2010 and Wald and Hosteller, 2010).

However, these huge drastic planning and developmental oversights cannot de-emphasize the unquantifiable value/need for recreational facilities in our cities today. Recreation is defined as a re-creation or restoration of depleted motor power or emotional state. It was also described as a socially acceptable leisure experience or activity that rests men from work, brings satisfaction often by giving them a change, and restores them for work (Hutchinson, 2005). Okolie (2008) described recreational facilities to provide green places for people to come together promoting communal bonding among city residents and infuses the social content of life.

Economically, He and Jia (2004) noted that parks and private planted areas surrounding buildings have a marked effect on many aspects of the quality of the urban environment and the richness of life in a city. Furthermore, in the residential community, landscape can affect the housing in the surroundings. Similarly, Chiesura (2004) contributed that, the presence of natural areas contributes to the quality of life in many ways and besides many environmental and ecological services, urban nature provides important social and psychological benefits to human societies, which enrich human life with meanings and emotions. Furthermore, Thompson (2002), acknowledged that, access to some form of "nature" is fundamental human need and therefore, a vital part of access to open space. In addition, Ahianba et al (2008) emphasized that physical environment is an important component of the environment and it is through that which organism, individual, community or population are in contact. As such, a well landscaped physical environment, also known as the built environment should be an integral part of the human environment.

\section{Planning/Design for Recreational Areas}

A well designed, landscaped and managed recreational centers and open spaces within the neighborhood/environment can offer play areas for children, communal space, and, serene environment and also contribute to the quality of life and well-being. Planning for recreational areas within human dwellings is an attempt to study human needs, scientific examination of contemporary resources, demographic growth and urban expansion. Planning is not complete without the proper distribution of recreational spaces and proposals 
for construction of required varied facilities to provide indoor and outdoor activities which make up balanced programme. The purpose of planning is to promote, extend and make available the necessary areas and physical plants for more perfect administration of public recreational service.

In developing recreational areas, factors for supply and demand are considered. The planner has a major role to play in the supply and resultant effects on landscape and also on recreational habits of the residents in urban areas. This is because leisure is essentially a matter of individual and normally reflected in the wide range of recreational activities open to him. Choice is always conditioned by certain factors such as age, marital status, income, educational background and also the availability of suitable resources and facilities to make proper use of them.

Demand as used by the planner "is the number of persons required to take part in particular recreational activities and hence is manifested in demand for facilities". This affects the design of various locations. The park has to be designed according to the demand of an area. Design is the search for forms that satisfy a program (Lynch,1976). It deals with particular solutions, while the programs is concerned with general characteristics and destined outcomes. Designs with programming are modified as a design process. Design is in all human thought; it is not restricted to geniuses or separate form practicability, or a sudden relation (Lynch,1976).

Facilities and utilities should be provided for public conveniences. These include dustbins, public toilets, canteens, snack bars, drink bars, ice cream stand, suya joints and benches. Every park and recreational area should have a well prepared emergency plan. The plan must be specially related to park activities provided; for example, size of the park, number of people using the park and the proximity of these facilities to the users which depends particularly on the size and type of recreational area.

\section{Facilities in Siting Public Parks}

Runte (1997), stated the basic facilities of a public park, which include; grassed area for field sports, paved areas for court games( basketball, volleyball),swimming pool, recreational building, picnic facilities, space for adult passive recreation, parking areas and rest rooms. He further illustrate in the table below, the age group, population and geographical area served.

Table 1.0 : Space Standards for Public Park.

\begin{tabular}{|l|l|l|l|l|}
\hline Nature of Space & $\begin{array}{l}\text { Age group to be } \\
\text { served }\end{array}$ & Approx. mini size & Unit needed & Service Area \\
\hline $\begin{array}{l}\text { Neighborhood park } \\
\text { playground }\end{array}$ & $5-14$ inclusive & $6-10$ acres & One per 4000-6000 & $1 / 2$ mile \\
\hline $\begin{array}{l}\text { Community Park } \\
\text { playground }\end{array}$ & $\begin{array}{l}\text { All groups but } \\
\text { youths especially }\end{array}$ & $15-20$ acres & $\begin{array}{l}\text { One per 20,000- } \\
25,000\end{array}$ & 1 mile \\
\hline $\begin{array}{l}\text { Specialized Park } \\
\text { and transitional sites }\end{array}$ & All groups & Variables & $\begin{array}{l}\text { Determined by } \\
\text { public demand }\end{array}$ & Variables \\
\hline National Park & All groups & Variables & $\begin{array}{l}\text { Determined by } \\
\text { public demand }\end{array}$ & $\begin{array}{l}\text { Several } \\
\text { communities }\end{array}$ \\
\hline
\end{tabular}

Source: Runte, 1997 Standards for Public Park

\section{Management of Recreational areas and Facilities}

Akintude and Akintude, (2002) described in their study the factors responsible for lack of development of recreational sport facilities; they include poor management, religion, land tenure system, politics, geographical location and the climate, socio-cultural background, the level of health awareness of individuals and the influence of pressure groups were examined. Good management is a vital aspect in the realization of set goals and objectives of any organization, institution or government especially in the case of those in charge of development of open space. It demands the need, aspiration and interests of people to be served is taken into consideration. Planning is for the people and recreation must be built around the desires and interests of the people for effective participation on the park and its users (Butler, 1940).

Management extends to the relationship between employers and the public in order to accomplish their set purpose. They must be one in mind and purpose. Poor relationship result in lack of enthusiasm to work, indifference in a half heated effort, and labor unrest. This will result in failure to understand the motives that makes man work, such as hopes and ambition.

Design and management are highly related. They involve the initiating organization and control of all those matters to enable effective results to be obtained; this involves a design staff, a design organization and a design process, the whole interaction taking place within design and drawing office of various kind( Lock and Farrow, 1989). According to Drucker (1954), management has the essence of creating a true whole that is larger than the sum of its parts. Thorncroft (1976), sees management as the science of organization and operation or at 
a practical level the act of directing and conducting affairs. Perhaps Drucker's conception of management as a multi- purpose organ that manages investment project manages managers and manages workers and work appears more comprehensive. This definition of management entails the manipulation of resources, people and skills for the achievement of set goals.

The development and progress of any society depends to a great extent on the prevailing state of management capacity. It is one of the most critical problems facing Nigeria in the present decade (Udoka, et al, 1978). The manageability of an investment is the extent to which it requires monitoring and periodic change (Ogbuefi, 2002). According to Opaluwah (2003) management of facilities involves the application of core principles in the procurement of facilities management. Such principles are explained below.

a) Planning and Programming: This involves the collation and usage of relevant data from sources as operation manuals, logbook, maintenance schedule and past experience to formulate and implement policies and procedures for effective of the facility.

b) Organizing: It is important for the facilities to be grouped either by their function or the building in which the facility is located. The method of ordering maintenance is also crucial as it determines the point of initiation of action.

c) Staffing: The personal engaged in the procurement of facility management must be deliberately trained, recruited and equipped to function effectively. Remuneration and other motivating factor must be deliberately catered for to enable such employees devote quality time to their duties.

d) Directing: In the case of facilities, the various specified maintenance activities and duration must be properly scheduled and affected religiously. Maintenance work must be directed in such a way that it does not impact negatively on production.

e) Controlling: As the other areas of management, facility managers must be necessarily control their work processes in order to achieve desired objectives.

f) Evaluating: Every management system must subject itself to periodic evaluation. This is necessary in order to assess the extent of success or failures. In the event of success, the manager needs to put in place structure not only continue to achieve success but to also improve on level of success. In the event of failure, a review of the causes of failure and probable mitigating steps are analyzed and taken in order to ensure a turn around.

Solutions to Problems Associated with Development of Recreational Facilities/Areas in Urban

\section{Communities}

Falade (1989) noted the ineffectiveness of the Nigerian planning Legislation in enforcing their proposed plans into developed recreational centers in cities. A singular arm is incapacitated in tackling the problems without the team services of all interested and affected groups. An effective plan is a necessity just as the collaboration of all stakeholders in decision making process is expedient. A concrete managerial procedure coupled with proper planning, design techniques and development structures should be pursued. This will incorporate the training and re-training of skilled manpower, innovation and flexibility in operation, monitoring, protection, conservation and management of recreational areas.

Due to the prevalence of social vices in our society, adequate provision should be made for supervision, security and safety of the easily removable facilities and equipment. Recreational facilities can be developed by various bodies in the community provided the goals and objective are understood by government and the general public. An individual in a community can embark on developing park facilities. In a situation where the development of recreational facilities is too costly to afford by a single person, a joint effort may be sought. In this case, many leisure lovers who have the means (capital) and are willing to sponsor part or whole programmes can come together to develop these facilities. Similarly, the individuals or philanthropists and the community may decide to levy themselves and join efforts in order to develop leisure facilities. Recreation clubs and halls are good example of this.

What matters most is for such government to play its part and encourage individuals in the community to assist. Our government should enforce and maintain good town planning in our cities including the so called rural areas and set an example to be set by providing a model recreation facility at least for each community. Government should embark upon thorough campaign and publicity for more public awareness to the importance of participation in recreational activities and the prospects it can bring to a city. This may be done through mass media, posters, seminars and clinics for both seniors and juniors staff of various work of life and the public in general the local, state and federal levels.

Government should embark upon thorough campaign and publicity for more public awareness to the importance of participation in recreational activities and the prospects it can bring to a community. This may be done through mass media, posters, seminars and clinics for both seniors and juniors staff of various work of life and the public in general the local, state and federal levels. 


\section{Conclusion}

A situation where government provides recreational facilities (e.g. sports stadium and centers); there is need for proper maintenance and sustenance. The cost of maintenance may force the government to commercialese such facilities and if care is not taken the bill may be too much for the public to bear, eventually the public may be discouraged and such facilities may not be put to its maximum use. Local government could help in establishing recreational parks and centre, however where hiring fees would be taken it should be very minimal .In the same vain there are other institutions such as corporations, industries, firms and companies that can assist greatly in the development of these facilities. The health of employees and the public should be the concern of any company that wants maximum workers, output. Many commercial and government institutions are now conscious of the importance of physical fitness and health programmes for their employees fostering the need for planning and developing more recreational areas.

\section{References}

[1] Ahianba,J.E,Dimunna,K.O., and Okogun,G.R.A (2008).Built Environment Decay and Urban Health in Nigeria. Human Ecology, 23(3),259-265.

[2] Akintude, P.G and Akintude, V.O.(2011).Solutions to Problems Associated with Development of Sports Faculties in Rural and Urban Communities. Department of Vocational and Special Education University of Calabar, Calabar Cross River State, Nigeria

[3] Alabi, M.O (2010). Prioritizing Factors of Failure in Controlling Physical Development in Nigerian Cities. Sustainable Development 12(2),215-231.

[4] Aluko, O.(2011).Sustainable Housing Development and Functionality of Planning Laws in Nigeria: Case Study of Cosmopolitan Lagos. Sustainable Development 4(5),64-74.

[5] Chiesura, A.(2004).The role of Urban Parks for the Sustainable City. Landscape and Urban Planning, 68(1), 129-138.

[6] Dong. W and Dong., W.(2011).The Construction of Ecological Functions of Urban Open Space. Applied Mechanics and Materials, 99-100,606-610.

[7] Esbah, H.,Deniz, B., and Cook, E.A (2005).Isolation Trends of Urban Open Spaces http://www.isprs.org/proceedings/xxxvi/8-w27.

[8] Falade, J.B.(1989). Amenity and Open Space in Nigeria. Land Use Policy, 6(2), 162-171.

[9] Fasakin.J.O (2009). Physical Development Strategies for Ondo State paper presentedat the Stakeholders Forum, Ondo State Ministry of Physical Planning and Urban Development, Akure, 23-24 November, Akure, Ondo State.

[10] He, J., and Jia, B.(2004).Towards a Sustainable Housing Environment; Ecological Landscape Principles and Practices in Large Housing Estates of Guangzhou, China. Paper Presented at the international Conference on Adequate and Affordable housing for all: Research. Policy and Practice . Center for urban and community Studies, Universityof toronto, Canada. June 24-27, 2004.Pp1-19.

[11] Hutchinson, S.L., and Kleiber, D.A.(2005).Gifts of the Ordinary :Casual Leisures Contributions to health and Wellbeing. World Leisure Journal,47(3), 2-16.

[12] Okoli,E.O(2008).The Development and management of Nigerian Cities. Paper presented at the NIESV Annual Conference, Transcorp Hilton Hotel, April7-13, 2008.

[13] Olumiji,J.(2009).Evolving a Planning Strategy for Managing Urban Sprawl in Nigeria. Human Ecology,25(3), 201-208

[14] Opaluwah, S.A (2003) Principles and Practice of Facilities management in Nigeria. Stillwater Publications. pp 6-10

[15] Ogundele, J.A and Jegede, A.O.(2011). Environmental Influence of Flooding on Urban Growth and Development of open Spaces. pp 12-16

[16] The Trust for Public Land.(2009). Community Benefits of Open Spaces .Available from http://www.njkeepitgreen.org/documents/community benefitsopenspace.pdf Accessed on 20/12/2009.

[17] Thomopson, C.W. (2002).Urban Open Spaces in the Open Spaces in the $21^{\text {st }}$ Century. Landscape and urban Planning.60(20),5972.

[18] Wald,D.M., and Hostetler, M.E (2010). Conservation Value of Residential of Florida's Land Development Regulations Sustainability,2(1536-15520).

Open Spaces: Designation and Management language 